$1-1-1992$

\title{
Association of short luteal phases with follicular development in sheep and cows
}

Robert A. Dailey

Follow this and additional works at: https://researchrepository.wvu.edu/ wv_agricultural_and_forestry_experiment_station_bulletins

\section{Digital Commons Citation}

Dailey, Robert A., "Association of short luteal phases with follicular development in sheep and cows" (1992). West Virginia Agricultural and Forestry Experiment Station Bulletins. 706T.

https://researchrepository.wvu.edu/wv_agricultural_and_forestry_experiment_station_bulletins/729 @ WVU. It has been accepted for inclusion in West Virginia Agricultural and Forestry Experiment Station Bulletins by an authorized administrator of The Research Repository@WVU. For more information, please contact ian.harmon@mail.wvu.edu. 


\section{Association}

of Short Luteal Phases

with Follicular Development
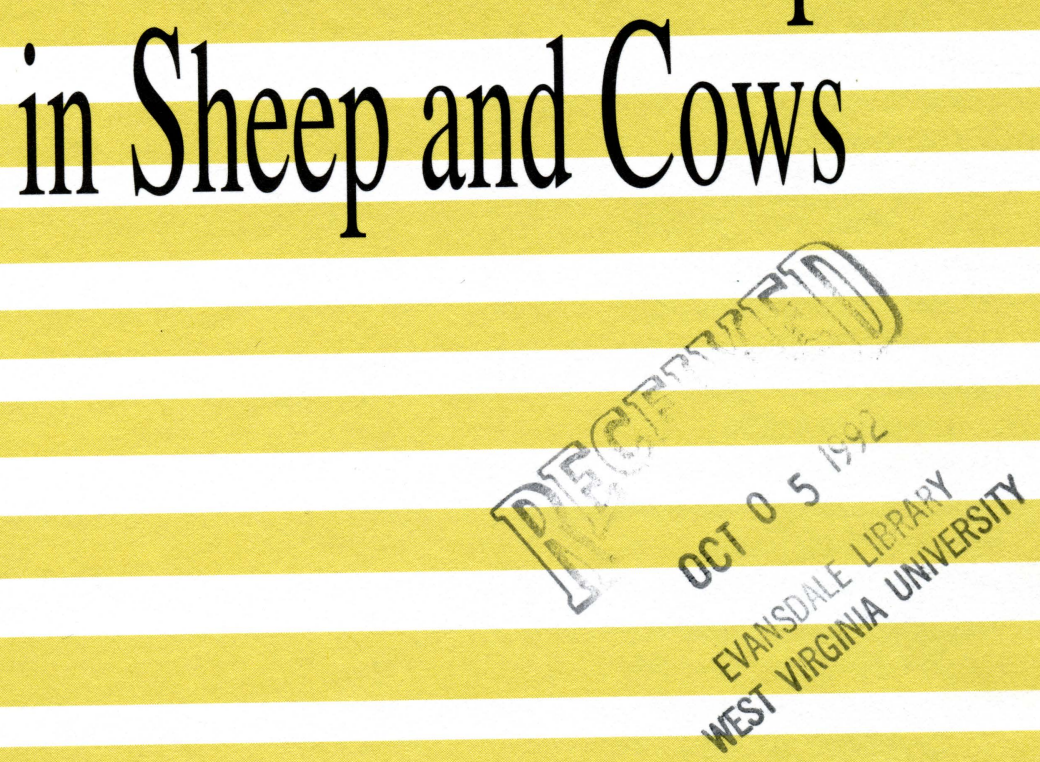

Bulletin 706T *ै August 1992

Agricultural and Forestry Experiment Station West Virginia University 


\begin{abstract}
Authors
R.A. Dailey and E.K. Inskeep are Professors of Animal Science, P.E. Lewis is Division Director, all in the Division of Animal and Veterinary Sciences, WVU College of Agriculture and Forestry. R.L. Butcher is Professor in the Department of Obstetrics and Gynecology, WVU School of Medicine.
\end{abstract}

\title{
Acknowledgments
}

The research reported is a summary of studies conducted at West Virginia University over a period of approximately 15 years. Principally, the research was conducted by graduate students in fulfillment of the requirements for their degrees. The publications of these students constitute most of the literature cited. Specifically, A.M. Benoit, K.F. Breuel, D.R. Deaver, R.L. Fogwell, M. Garcia-Winder, S.K. Johnson, D.H. Keisler, G.H. Larson, G.S. Lewis, D.S. Mallory, and L.M. White were doctoral candidates; J.G. Berardinelli, D.A. Coleman, J.A. Hall, J.S. Ottobre, B.R. Pratt, and R.H. Usmani were candidates for master's and doctoral degrees; and R.W. Bryner, A.L. Connor, D.A. Cooper, D.A. Carver, V.I. McCormick, W.R. McVey, Jr., E.M. Meisterling, C.E. Sheffel and W.J. Silvia were master's candidates. D.R. Colborn, S. Meredith, F.N. Schrick and D.L. Vincent were postdoctoral fellows. A.W. Lishman was a visiting professor on sabbatical leave from the University of Natal, J.E. Reber was a visiting master's student from Clemson University and P.E. Villeneuve was a visiting doctoral student from Laval University.

The work was supported by Hatch Project 224, a contribution to Northeast Regional Project 72; Hatch Project 321, a contribution to Northeast Regional Project 161; State Project 103 (Animal Health); a grant from Select Sires, Inc.; four USDA grants (83-CSRS-2-2190, 86-CRCR-1-2138, 87CRSR-2-3074, 89-37240-4714) and a study grant from the Food and Agriculture Organization of the United Nations. The authors recognize that work on this problem has been done at a number of other stations and that such work has influenced our thinking. References to those studies can be found in the publications in the literature cited.

\author{
West Virginia University \\ Agricultural and Forestry Experiment Station \\ College of Agriculture and Forestry \\ Robert H. Maxwell, Director \\ Morgantown
}




\section{Association of Short Luteal Phases with Follicular Development in Sheep and Cows}

R.A. Dailey, R.L. Butcher, E.K. Inskeep and P.E. Lewis

The work summarized illustrates an integrated research program by a team of academic scientists and trainees. Individual research projects were independent entities, but each yielded data that were useful in the interpretation of other projects and provided a basis for subsequent experiments, all related to the relationships between follicular development and luteal function. The following discussion addresses research that has been conducted at the West Virginia Agricultural and Forestry Experiment Station that centered on studies of short luteal phases in sheep and cattle.

\section{Introduction}

A reproductive management objective for producers is to have every cow calve annually. To achieve this goal, cows must return to estrus and conceive within 90 days after calving. Although some cows show estrus early in the postpartum period, others have extended periods of anestrus, often beyond 100 days postpartum. In addition, many cows show luteal phases shorter than the normal duration prior to or during the first postpartum estrous cycle. In ewes, cows and water buffaloes, these short luteal phases occur just prior to puberty and in the early postpartum period, as well as during the transition from seasonal anestrus to the breeding season in sheep. Completion of pregnancy from matings preceding these short cycles does not occur.

The basis for short-lived corpora lutea could involve inadequate follicular development, decreased responsiveness to a luteotropin, alterations in the patterns of secretion of the gonadotropic hormones LH and/or FSH by the pituitary, increased secretion of prostaglandin (PG) $F_{2} \alpha$ by the uterus or increased sensitivity of corpora lutea to $\mathrm{PGF}_{2} \alpha$. The discussion will cover puberty, breeding season, and both seasonal and postpartum anestrus.

\section{Puberty}

Brief rise(s) in progesterone have consistently been observed in the peripheral circulation before the first estrus. In our initial studies (Berar- 
dinelli et al., 1979, 1980), the goal was to determine the source of that progesterone. In heifers and ewe lambs, when concentrations of progesterone were elevated in blood from an ovarian vein, the associated ovary contained luteal tissue. Removal of that ovary resulted in an immediate drop in peripheral progesterone to undetectable concentrations (Figure 1). In heifers, the luteal structure was embedded within the ovary and histologically had cells indistinguishable from cells of a corpus luteum. In lambs, the luteal structure was visible on the surface of the ovary (Keisler et al., 1983, Figure 2) but did not always have an ovulation papilla (Berardinelli et al., 1980).

We next determined whether the uterus was involved in regulating the lifespan of these structures (Keisler et al., 1983). Ewe lambs were hysterectomized either well before the expected rise in progesterone or on the day of the first detectable rise in progesterone in the peripheral blood. Hysterectomy prolonged the lifespan but did not increase the secretory activity of the luteal structure. Because some ewe lambs reached puberty without first showing a short luteal phase, we concluded that formation of the short-lived structure was not essential for sexual maturation. In addition, one can surmise that a brief period of progesterone was not required for puberty, although ewe lambs do not show estrus normally until after exposure to progesterone for either a brief period or a normal luteal phase. In another trial, Berardinelli (1979) did find an earlier attainment of puberty in heifers after treatment with exogenous progesterone.

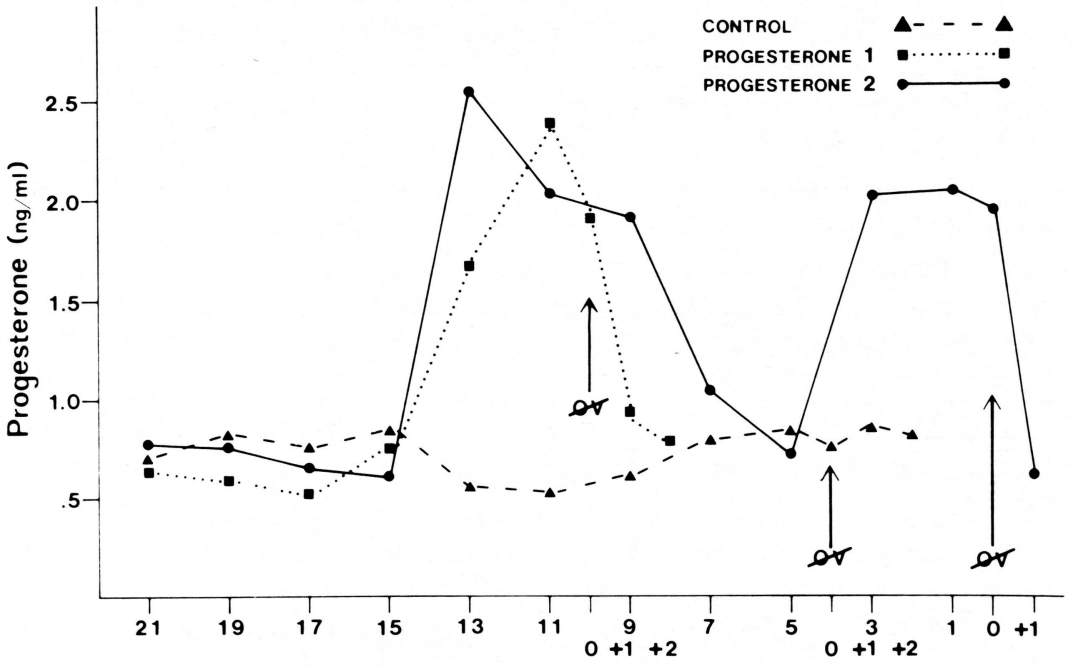

Days

Figure 1. Graph depicting the fall in concentrations of progesterone when the ovary with the high ovarian venous concentration is removed after either the first or second increase. 


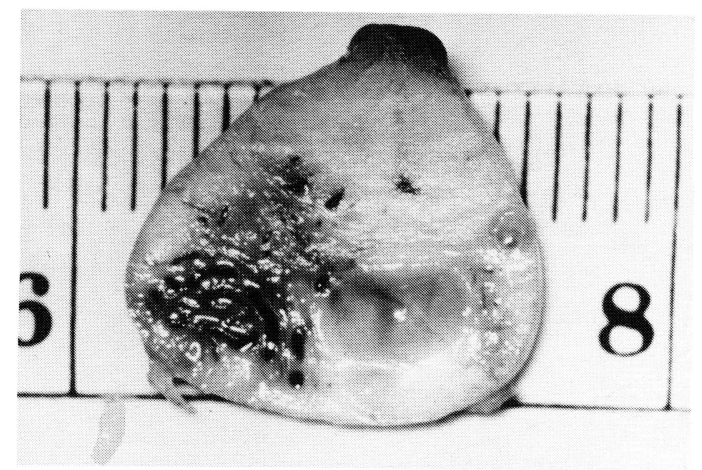

Figure 2. Photograph of a bisected ovary of a pubertal lamb. The luteal structure has a papilla and extrudes out of the medulla of the ovary.

\section{Breeding Season}

Because the onset of puberty and the associated short luteal phases are difficult to predict, we used studies in ewes during the breeding season to determine some of the factors causing short-lived luteal structures. Coleman et al. (1983) removed the preovulatory follicle at estrus. Another follicle grew to preovulatory size within four days. This pattern continued after subsequent removal of at least three ensuing follicles. When a follicle was finally allowed to ovulate, the resulting corpus luteum either had a short lifespan or a normal lifespan with reduced secretion of progesterone. Notably, the ewes had preovulatory surges of FSH and LH that were indistinguishable from those of ewes having normal luteal phases, suggestive of follicular incompetence.

In a second study, White et al. (1987) used the Coleman model and removed the second preovulatory follicle in a sequence, either before or after the preovulatory surge of $\mathrm{LH}$, to determine steroidogenic profiles of these follicles destined to form subnormal corpora lutea. Abnormal profiles of progesterone comparable to those observed by Coleman were found in contemporary ewes allowed to ovulate the second follicle, and normal surges of $\mathrm{LH}$ and FSH accompanied the formation of those corpora lutea. Only the follicles removed prior to the surge of LH showed demonstrable changes in the concentrations of steroid. Concentrations were reduced for estradiol in the theca and granulosa, androstenedione in the granulosa, and progesterone in the follicular fluid (Figure 3). Neither the estrogen to androgen ratio nor the estrogen to progesterone ratio differed, which led us to suggest that the follicles were not atretic but had reduced steroidogenic capability. Indeed, when follicles destined to form subnormal corpora lutea were incubated in vitro with androstenedione, a precursor of estradiol, the granulosa produced 
as much estradiol as that from control follicles (Colborn and Dailey, 1992). Perhaps they ovulated prematurely relative to follicles in a normal estrous cycle. In a series of trials (Benoit, 1991), we examined whether an induced reduction in concentrations of estradiol would result in subnormal luteal function. Using an aromatase inhibitor (CGS16949A, CIBA-Geigy, Inc.) injected every 12 hours into follicular phase ewes, we were able to reduce

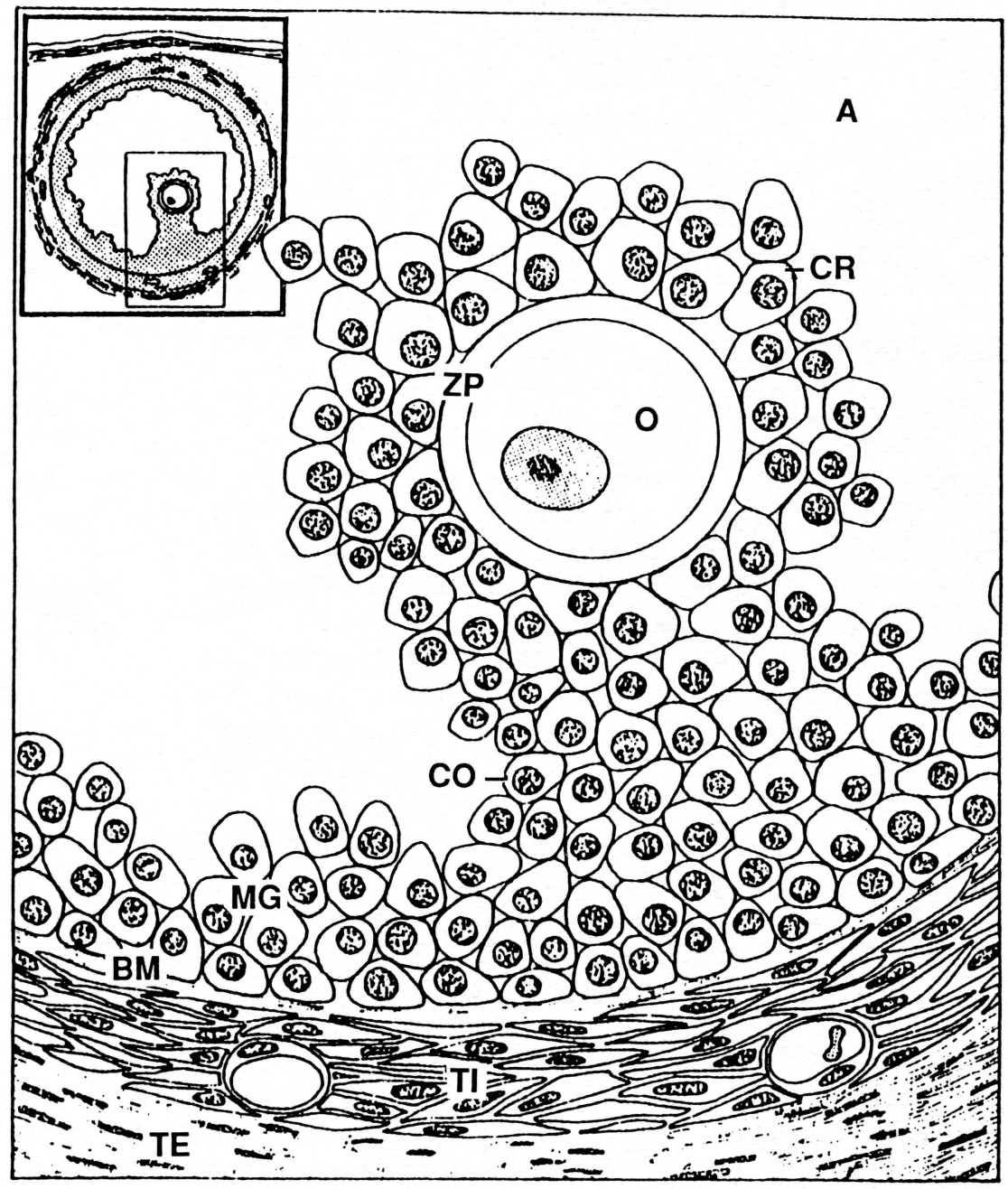

Figure 3. Schematic of a section of a mammalian ovarian follicle. The components are: $\mathrm{A}$, antrum; $\mathrm{BM}$, basement membrane; $\mathrm{CO}$, cumulus oophorous; $\mathrm{CR}$, corona radiata; $\mathrm{MG}$, membrana granulosa; $\mathrm{O}$, oocyte; $\mathrm{TE}$, theca externa; TI, theca interna; $\mathrm{ZP}$, zona pellucida. 
ovarian secretion and peripheral concentrations of estradiol. However, there was no effect on the subsequent luteal phase concentrations of progesterone. Because of the injection scheme, concentrations of estradiol were not depressed continuously. Therefore, in another study the inhibitor was injected more frequently, at 8-hour intervals. This time we were able to continuously depress concentrations of estradiol. This treatment blocked the surge of LH due to the lack of any increases in estradiol, delayed estrus and produced corpora lutea in response to the injection of human chorionic gonadotropin. Corpora lutea did not produce progesterone for several days and were considered dormant. During dormancy, these ewes showed estrus and some of them ovulated a second time, while others developed follicular cysts or formed no new luteal structures. Once secretion of progesterone was initiated, the profiles were of normal duration and reached concentrations similar to those of ewes with normal corpora lutea. Thus, a normal profile of estradiol is not required for formation of corpora lutea with normal lifespan, but alterations in the profile can disrupt the luteinization process or prolong the normal period of transition from a follicular structure to a luteal structure.

\section{Anestrus}

Anestrus characteristically follows parturition and often is interrupted by a short luteal phase immediately preceding the onset of normal estrous cycles. In fall-lambing ewes (Lewis et al., 1981), we examined the effect of progestogen treatment prior to induction of ovulation with an injection of gonadotropin releasing hormone $(\mathrm{GnRH})$ on day 22 postpartum. Progestogen ( $20 \mathrm{mg}$ flurogestone acetate by intravaginal pessary) for 4 days did not alter the proportion of the ewes that had shortened luteal phases (a mean of 5 ewes per group of 8). Length of the short luteal phases was actually shortened by treatment with progestogen. However, length of the luteal phase was not related to the pattern of release of $\mathrm{LH}$ nor was it related to concentrations of $\mathrm{PGF}_{2} \alpha$ in utero-ovarian venous plasma, measured concurrently on day 7. A single-point measurement probably was not adequate to assess patterns of $\mathrm{PGF}_{2} \alpha$. A longer progestogen treatment improved luteal function (G.S. Lewis, personal communication). Because most of the ewes had short luteal phases when induced at 22 days postpartum, we induced ovulation at 27 or 43 days postpartum in another trial (Sheffel, 1980). None of 11 anestrous ewes had short luteal phases in that study.

Ewes lambing during the anestrous season were induced to form corpora lutea on day 14 postpartum (McCormick, 1988). Ovulation occurred more frequently on the ovary ipsilateral to the non-gravid uterine horn than on the ovary ipsilateral to the previously gravid horn, and these corpora lutea produced greater amounts of progesterone. Thus, either the corpus luteum 
of pregnancy or the gravid horn impaired ovarian function after parturition. Then, the corpus luteum was removed during pregnancy. Fewer follicles were found on day 20 postpartum in those ewes, and fewer of them ovulated after injection of hCG on day 20 compared to the response to hCG injection in intact ewes (Hall et al., 1992). There was a local positive effect of the corpus luteum on follicular development, but there was no influence of the corpus luteum on which ovary ovulated. Induced corpora lutea were more frequently formed in the ovary contralateral to the previously pregnant horn, as observed by McCormick (1988). However, presence of the corpus luteum of pregnancy resulted in a longer lifespan for corpora lutea on that ovary than on the contralateral ovary, which did not contain a corpus luteum of pregnancy. Thus, the influence of the corpus luteum might have been through development of a more competent follicle, possibly through longer term effects of progesterone. McCormick (1988) showed that progesterone treatment resulted in a greater release of $\mathrm{PGF}_{2} \alpha$ and $\mathrm{PGE}_{2}$ into the utero-ovarian vein draining the previously gravid horn than the non-gravid horn. Villeneuve et al. (1989) found that treatment of early postpartum ewes with PGF $_{2} \alpha$ resulted in enhanced development of follicles, with a greater number of follicles on the ovary ipsilateral to the previously gravid uterine horn, as compared to control ewes. After induction of ovulation, more ewes treated with $\mathrm{PGF}_{2} \alpha$ had corpora lutea with normal lifespan or function than control ewes $(6 / 10$ vs $0 / 3)$.

McCormick (1988) noted that once lambs began nursing, samples were difficult to collect from the utero-ovarian catheters. Earlier, we had found that placement of a utero-ovarian catheter into the vein draining the ovary containing a corpus luteum prolonged the lifespan of that corpus luteum (A.L. Conner, unpublished), presumably by interfering with the countercurrent transfer of $\mathrm{PGF}_{2} \alpha$ from the uterine vein to the ovarian artery. These problems can now be circumvented by using a catheter placed via the lateral saphenous vein into the caudal (posterior) vena cava (Figure 4, Benoit and Dailey, 1991). This method also supercedes catheterization of the posterior vena cava in cattle via the tail vein, an approach that had a low success rate for catheter replacement because of plexuses in the tail vein (Carver, 1989).

We were unable to clearly test hypotheses concerning factors influencing the occurrence of short luteal phases in the postpartum ewe. In a study using anestrous ewes (Benoit, 1991), we examined the association of preovulatory estradiol with the subsequent luteal phase. Anestrous ewes were treated for 9 days with half of a norgestomet implant and then with GnRH every 2 hours for 36 hours. Then they were induced to ovulate by injecting hCG. Induced luteal phases were found in $72 \%$ of the ewes, and $78 \%$ of these luteal phases were normal. Ewes were divided into those having high and low profiles of estradiol in the peripheral plasma. In this case, ewes with higher estrogen had more short luteal phases, possibly because of negative feedback 
effects on gonadotropin secretion. On the other hand, high concentrations of estrogen in the utero-ovarian vein were not associated with the subsequent level of function of corpora lutea.

Water buffaloes of the Nili-Ravi breed, which are selected mainly as dairy animals, have very long postpartum intervals. With the arrival of a student from Pakistan, we studied the role of the short luteal phase in the return to estrus in these animals (Usmani et al., 1985a, 1985b, 1990). The number of corpora lutea formed before first postpartum estrus ranged from 0 to 5 and averaged 1.2 per buffalo. The initial luteal phase was for 7.9 to 15.9 days in estrous cycles of 17.7 to 24.6 days, indicating shortened luteal function and prolonged follicular phases before second estrus. Although supplemental prepartum feeding did not affect these variables, limited suckling lengthened the intervals to first rise in progesterone and first estrus, shortened the length of the first estrous cycle in one experiment and doubled the average number of luteal phases before first estrus in another. Thus, the short luteal phase is important in the timing of the onset of postpartum estrus in dairy water buffaloes.

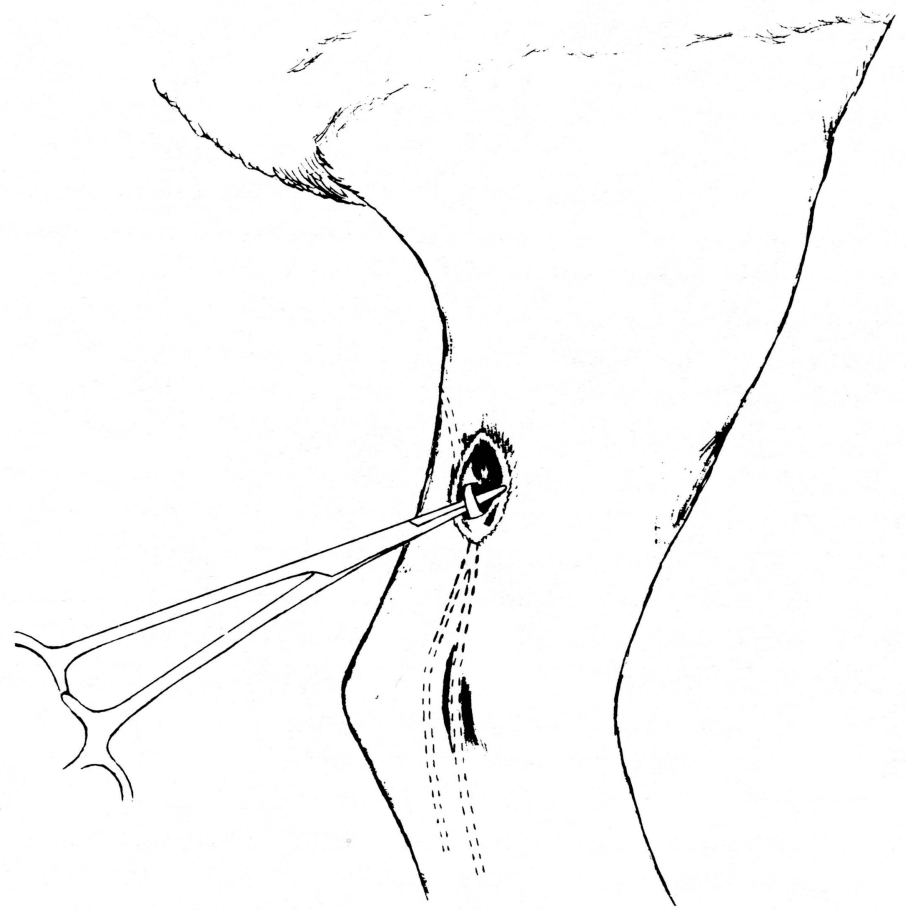

Figure 4. Schematic of the placement of a catheter via the lateral saphenous vein into the caudal (posterior) vena cava. 
While doing these studies, we made another interesting observation. Ovarian follicles were located more frequently in the central portion of the ovary $(41 \%)$ than in the medial $(31 \%)$ or lateral $(28 \%)$ portions when the ovary was supplied by a single branch, as compared to two branches of the ovarian artery. Previously (Dailey et al., 1982), we had shown that more follicles and corpora lutea were found in the middle of the ovary of the sheep than on the ends. Blood supply of the sheep ovary enters through the hilus, and number of follicles in a standardized area was correlated with ovarian mass. However, occurrence of corpora lutea in a standardized area was not correlated with ovarian mass. We had found a similar relationship for location of palpated corpora lutea and follicles in ovaries of cows and heifers (Berardinelli, Dailey and Inskeep, unpublished). In the water buffaloes, corpora lutea were found more frequently in the portion of the ovary adjacent to the point of arterial entry regardless of the number of branches. Perhaps lifespan of a corpus luteum might be similarly affected.

In other experiments, we examined the lifespan of corpora lutea induced in early postpartum cows. In initial studies (Lishman et al., 1979), postpartum anestrous beef cows had corpora lutea induced by injection of GnRH. In the majority of cows, the corpora lutea had short lifespans and the incidence of these was not affected by treatment with FSH and/or estradiol during the 3 to 4 days before induction of corpora lutea. We then developed a model using 9 days of treatment with norgestomet in anestrous cows, usually 25 to 35 days postpartum (Pratt et al., 1982). After induction of ovulation with either hCG or $\mathrm{GnRH}, 70 \%$ to $80 \%$ of norgestomet-treated cows had normal lifespan and function of the corpus luteum, while nearly all of the controls had short luteal phases. In a cooperative study with the University of Missouri (Copelin et al., 1988), a combination of hysterectomy and treatment with norgestomet was used to test the responsiveness of the induced corpora lutea to a subluteolytic (10mg) dose of $\mathrm{PGF}_{2} \alpha$ and to measure PGF $2 \alpha$ and $\mathrm{PGE}_{2}$. Concentrations of $\mathrm{PGF}_{2} \alpha$ and $\mathrm{PGE}_{2}$ in uterine flushings, endometrial tissue and utero-ovarian blood at the time of hysterectomy ( 3 days after induction of ovulation) did not differ with norgestomet treatment. Neither was there an effect of norgestomet on sensitivity of the corpora lutea to $\mathrm{PGF}_{2} \alpha$. Hysterectomy did prolong the lifespan but did not alter the responsiveness of induced corpora lutea to a luteolytic dose $(25 \mathrm{mg})$ of $\mathrm{PGF}_{2} \alpha$.

More recently Cooper et al. (1991) measured concentrations of PGF $_{2} \alpha$ in vena caval blood during both the implant period of norgestomet and the induced luteal phase. Concentrations of $\mathrm{PGF}_{2} \alpha$ were higher in norgestomettreated cows than control cows during days 3 to 5 of the implant period but lower on days 4 to 9 after the induction of ovulation. There was no effect on peripheral concentrations of 15-keto 13,14-dihydro-PGF $2 \alpha$ (PGFM), a metabolite of $\mathrm{PGF}_{2} \alpha$, or oxytocin during the luteal phase. The increase in concentrations of $\mathrm{PGF}_{2} \alpha$ during the implant period could bring about 
enhanced follicular development (Villeneuve et al., 1989) and thus lengthen the luteal phase. However, prevention of that rise by treating the cows with a prostaglandin synthetase inhibitor did not alter the subsequent luteal phase (Johnson et al., 1992). Neither did treatment with $\mathrm{PGF}_{2} \alpha$ - which increased follicular development - affect the length of the short luteal phase in control cows.

Ottobre et al. (1980) found that in cyclic ewes the signal that times the increase in uterine secretion of $\mathrm{PGF}_{2} \alpha$ is the increase in progesterone. Carver (1989) found that the pattern of secretion of $\mathrm{PGF}_{2} \alpha$ on days 16 and 17 of the estrous cycle was not altered if the cows were ovariectomized on day 8 and given $150 \mathrm{mg}$ of progesterone daily through day 17 . These and other studies showed that progesterone plays a key role in controlling the timing and pattern of release of PGF $_{2} \alpha$ (Ottobre et al., 1984; Vincent and Inskeep, 1986; Vincent et al., 1986). In the anestrous cow, it appears that PGF $\alpha$ rises immediately when the uterus first detects progesterone, but rises at the time of a normal cyclic increase of $\mathrm{PGF}_{2} \alpha$ after progesterone is detected a second time. Based upon Johnson's data, the earlier rise in $\mathrm{PGF}_{2} \alpha$ did not mediate this effect of the first rise in progesterone on the response to the second rise.

In several studies we have been able to characterize the follicle during or after treatment with norgestomet. The diameter of the largest follicle did not differ between control and norgestomet-treated animals at the time of (Pratt et al., 1982) or the day after removal of the implant (Johnson et al., 1991). However, just prior to ovulation, the largest follicle in norgestomettreated cows had a greater diameter (Garcia-Winder et al., 1988) and more receptors for LH (Inskeep et al., 1988) than the largest follicle in control cows. Concentrations of estradiol in granulosa of the largest follicle were greater during the latter part of the implant period (by day 8; Johnson et al., 1991) and just prior to ovulation (Garcia-Winder et al., 1988) in norgestomettreated cows than in control cows, but follicular content of cAMP was not increased by the day after implant removal (Johnson et al., 1991). There was an increase in concentrations of peripheral LH on day 6 of the implant period (Garcia-Winder et al., 1985), and peripheral concentrations of estradiol were increased after removal of the implant in comparison to control cows (Sheffel et al., 1982; Garcia-Winder et al., 1987; Breuel et al., 1988; and Johnson et al., 1991). However, when Meisterling et al. (1987) measured the concentrations of estradiol in milk from postpartum dairy cows having first luteal phases that were either short or normal, the concentrations of estradiol preceding that luteal phase did not differ between classification of cows. The concentrations of estradiol preceding the second luteal phase, which was of normal duration, were greater for cows that initially had a short luteal phase than for cows with a normal first luteal phase. Interestingly, the short luteal lifespan corresponded with the duration of norgestomet treatment, and each was followed by increased concentrations of estradiol. 
Larson (1987) found that approximately $85 \%$ of 21 early (16 to 40 days) postpartum beef cows implanted with norgestomet had an induced corpus luteum when their concentrations of estradiol at the time of injection of hCG equalled or exceeded that of the mean of the group. In contrast, 26/57 (39\%) of norgestomet-treated cows with lower levels of estradiol had an induced corpus luteum. Achieving a normal lifespan, however, was not as likely as ovulation; $11 / 18(61 \%)$ compared to $8 / 26(31 \%)$ of the cows that ovulated had corpora lutea with a normal lifespan. Hence, higher estradiol was associated with greater responsiveness of the follicle, as was shown by the studies in sheep by Benoit and in cows by Johnson and discussed previously. However, raising estrogen concentration by exogenous injections (Lishman et al., 1979) did not increase either incidence of ovulation or luteal lifespan, which led us to suggest that estrogen acts within the follicle to enhance responsiveness, and necessary concentrations may not be achieved by simple injections into the cow.

Lishman et al. (1979) were unable to increase the responsiveness of follicles of postpartum anestrous beef cows by injections of FSH, and all corpora lutea that were formed were short-lived. Injections of bFF to cows throughout treatment or for the first 6 days of treatment with norgestomet blocked the formation of corpora lutea in anestrous postpartum beef cows (Larson, 1987). Cows treated with bFF from days 3 to 6 of the norgestomet implant period ovulated in response to exogenous hCG but tended to have more short-lived corpora lutea. Hence, treatment with bFF during days 1 to 3 would seem to influence the responsiveness of the follicle (independent of effects on peripheral concentrations of estradiol), whereas treatment from days 3 to 6 would affect the longevity of the induced corpus luteum. Stated differently, the treatment with bFF 8 to 11 days before ovulation would affect responsiveness, while treatment 5 to 8 days before ovulation would affect luteal lifespan. Larson et al. (1987) had shown in sheep that treatment with bFF on days 11 through 15 of the estrous cycle extended the follicular phase by 3 days but resulted in corpora lutea with normal lifespan. Although it is tempting to ascribe these effects to the lowered concentrations of FSH reaching the ovary, bFF also directly reduced the number of follicles above $2 \mathrm{~mm}$ in diameter in pituitary stalk-sectioned ewes (Larson et al., 1991).

\section{Fertility at First Postpartum Estrus}

When calves are weaned from cows at about day 30 postpartum, the first ovulation-which occurs in an average of five days - is accompanied by estrus. If such cows are pretreated with progestogen, the luteal phase following this estrus is usually of normal length, whereas it is usually of short duration in control cows. Thus, we have been able to use the model of norgestomet-treated and control cows, with calves weaned two days prior to 


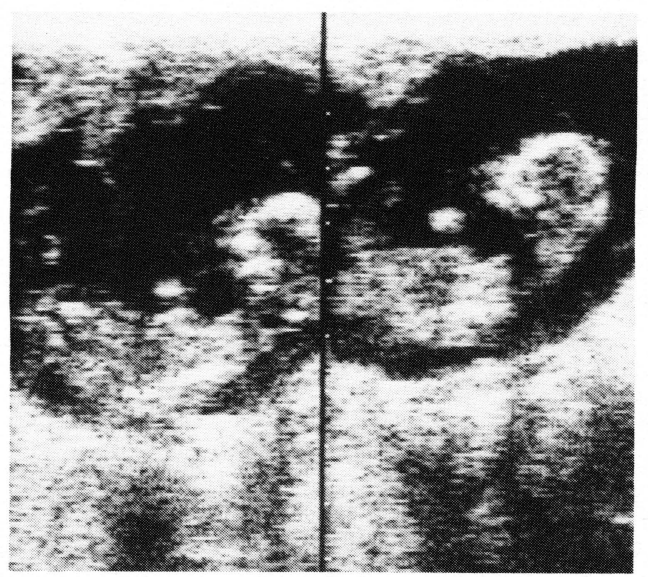

Figure 5. Photograph of ultrasonographic recording of an embryo in a cow.

implant removal, to study factors affecting fertility (Figure 5). In our initial studies, Breuel et al. (1988) found that rates of embryo and/or ova recovery (89\%), fertilization (70\%) and fertilized ova having normal embryonic development to day $3(88 \%)$ did not differ between norgestomet-treated and control cows. Transport into the uterus was confirmed by recovery of embryos on day 6 after estrus in cows expected to have short (6/7) or normal (5/7) luteal phases (K.F. Breuel, A.W. Lishman and R.L. Butcher, unpublished). Feeding $2 \mathrm{mg}$ of melengestrol acetate, a synthetic progestogen, daily (days 3 to 35 after estrus) or injection of $100 \mathrm{mg}$ progesterone twice daily did not maintain pregnancy in control cows with short luteal phases or enhance pregnancy rate in norgestomet-pretreated cows with normal luteal phases (Breuel et al., 1989, F.N. Schrick, unpublished). Thus, short luteal phases must not be the only limiting factor in low pregnancy rates. In fact, if embryonic death is predestined, the short luteal phase may actually shorten the interval from parturition to conception. Factors involved may include quality of embryos and/or limitations in uterine function. To test these possibilities, studies using reciprocal transfers of embryos between cyclic cows and early postpartum cows were initiated.

The first study tested whether the ability of the uterus to maintain pregnancy differed between cows with short and normal luteal phases when provided exogenous progesterone and normal embryos (Reber et al., 1991). Two good-quality frozen-thawed embryos were transferred nonsurgically on day 7 postestrus to each of 20 control and 17 norgestomet-treated cows. Pregnancy rates were $30 \%$ and $59 \%$, respectively. Thus, even when good embryos and supplementary progesterone were provided, more embryos 
were lost in control cows. The second study is still in progress, but two embryos (11\%) flushed from control cows on day 7 have survived as pregnancies when transferred to normally cycling heifers (F.N. Schrick and R.L. Butcher, unpublished data). Therefore, our preliminary conclusion is that approximately half of the loss of pregnancy in control cows is due to defective oocytes while the other half can be attributed to poor uterine environment, neither of which can be overcome by simply replacing the progesterone deficiency.

\section{Conclusion}

The short or inadequate luteal phase occurs in a majority of prepubertal lambs and heifers and anestrous ewes and cows prior to the occurrence of normal luteal phases. Short luteal phases are not essential for the onset of normal estrous cyclicity, and the occurence of short luteal phases does not favor normal fertility. From our combined studies, we have shown that short-lived corpora lutea in the ovary cause the transitory increases in peripheral concentrations of progesterone that precede first estrus after a period of anestrus. The occurrence of these short luteal phases is not due to inadequate secretion of FSH or LH. Follicles that are transformed into these short-lived structures secrete less estradiol, yet are not atretic based on ratios of estradiol:progesterone or estradiol:androgen. Hysterectomy prolongs the lifespan of these structures.

There is ample evidence to support the premise that short-lived corpora lutea result from increased early secretion of $\mathrm{PGF}_{2} \alpha$ by the uterus, but not from altered timing or duration of the surge of LH or increased sensitivity to $\mathrm{PGF}_{2} \alpha$. One can surmise that maturation of the system that times the release of $\mathrm{PGF}_{2} \alpha$ might be necessary for obtaining a normal luteal phase, and that at least part of that signal system involves exposure to progesterone. In sheep and cattle, the follicle destined to have an abbreviated lifespan or reduced function had less steroidogenic capability than the follicle destined to form a normal corpus luteum. There could be additional factors involved in describing adequate follicular development. Part of the function of that development might be involved in the transformation from follicular to luteal tissue.

\section{Implications}

By increasing our understanding of the manner in which the reproductive system matures at puberty and how it is restored to normal cyclic function after parturition or seasonal anestrus we have discovered several possible answers for improvements in reproductive efficiency in cattle and sheep. For 
example, the calving interval was reduced by nearly two months in $58 \%$ of the beef cow herd by the combination of norgestomet implants, early weaning of the calf and transfer of two good embryos on day 7 after estrus. Similarly, in concurrent tests designed to apply what had been learned in anestrous ewes, pregnancy rates as high as $55 \%$ to $71 \%$ were obtained to a single service in April. In this case, the treatment used was an injection of $25 \mathrm{mg}$ progesterone, introduction of rams at a ratio of one per 10 to 15 ewes on the same day and synchronization of estrus 14 to 16 days later with $\mathrm{PGF}_{2} \alpha$.

As noted in the introduction, it should be the goal of each beef producer to have cows calve at an annual interval. Under current management practices, a producer could realize a profit of approximately $\$ 50$ per cow if the calving interval was reduced as described above. That is, if the calving interval is reduced by 60 days in 58 cows of a 100 cow herd, the average reduction for the herd would be 35 days $(60 \times .58=35)$. Assuming an average daily gain of 2 pounds and a selling price of $\$ 85 / 100$ pounds, the calf would weigh 70 pounds more at sale date and would bring $\$ 59.50$ more.

\section{Literature Cited}

Benoit, A.M. 1991. Production of estradiol by the preovulatory follicle and lifespan and function of the subsequent corpus luteum. Ph.D. Dissertation, West Virginia University, Morgantown.

Benoit, A.M. and R.A. Dailey. 1991. Catheterization of the caudal vena cava via the lateral saphenous vein in the ewe, cow, and gilt: An alternative to utero-ovarian and medial coccygeal vein catheters. J. Anim. Sci. 69:29712979.

Berardinelli, J. 1979. Factors involved in the attainment of puberty in female domestic-ruminants. Ph.D. Dissertation, West Virginia University, Morgantown.

Berardinelli, J.G., R.A. Dailey, R.L. Butcher and E.K. Inskeep. 1979. Source of progesterone prior to puberty in beef heifers. J. Anim. Sci. 49:1276-1280.

Berardinelli, J.G., R.A. Dailey, R.L. Butcher and E.K. Inskeep. 1980. Source of circulating progesterone in prepubertal ewes. Biol. Reprod. 22:233-236.

Breuel, K.F., P.E. Lewis, E.K. Inskeep and R.L. Butcher. 1988. Relationship of hormonal profiles to fertility in anestrous postpartum beef cows. J. Anim. Sci. 66 (Suppl. 1):379.

Breuel, K.F., P.E. Lewis, E.K. Inskeep and R.L. Butcher. 1989. Fertility in early weaned beef cows pretreated with norgestomet: Embryonic survival.J. Anim. Sci. 67 (Suppl. 1):351. 
Carver, D.A. 1989. Ovarian regulation of uterine secretion of $\mathrm{PGF}_{2} \alpha$ in nonpregnant cows. M.S. Thesis. West Virginia University, Morgantown.

Coleman, D.A. and R.A. Dailey. 1983. Effects of repeated removal of large ovarian follicles and treatment with progestin in the ewe. Biol. Reprod. 29:586-593.

Colborn, D.R. and R. A. Dailey. 1992. Steroid production by ovine follicles destined to form sub-normal corpora lutea. J. Anim. Sci. 70:(Suppl. 1).

Cooper, D.A., D.A. Carver, P. Villeneuve, W.J. Silvia and E.K. Inskeep. 1991. Effects of progestogen treatment on concentrations of prostaglandins and oxytocin in plasma from the posterior vena cava of postpartum beef cows. J. Reprod. Fert. 91:411-421.

Copelin, J.P., M.F. Smith, H.A. Garverick, R.S. Youngquist, W.R. McVey, Jr. and E.K. Inskeep. 1988. Responsiveness of bovine corpora lutea to $\mathrm{PGF}_{2} \alpha$ : Comparison of corpora lutea anticipated to have short or normal life spans. J. Anim. Sci. 66:1236-1245.

Dailey, R.A., R.L. Fogwell and W.V. Thayne. 1982. Distribution of visible follicles on the ovarian surface in ewes. J. Anim. Sci. 54:1196-1204.

Garcia-Winder, M., P.E. Lewis, R.W. Bryner, R.D. Baker, E.K. Inskeep and R.L. Butcher. 1988. Effect of age and norgestomet on endocrine parameters and production of embryos in superovulated beef cows. J. Anim. Sci. 66:1974-1981.

Garcia-Winder, M., P.E. Lewis, D.R. Deaver, V.G. Smith, G.S. Lewis and E.K. Inskeep. 1985. Endocrine profiles associated with life span of induced corpora lutea in postpartum beef cows. J. Anim. Sci. 62:1353-1362.

Garcia-Winder, M., P.E. Lewis, E.C. Townsend and E.K. Inskeep. 1987. Effects of norgestomet on follicular development in postpartum beef cows. J. Anim. Sci. 64:1099-1109.

Hall, J.A., R.A. Dailey, E.K. Inskeep and P.E. Lewis. 1992. Influence of the corpus luteum of pregnancy on ovarian function in postpartum ewes. (In preparation).

Inskeep, E.K., T.D. Braden, P.E. Lewis, M. Garcia-Winder and G.D. Niswender. 1988. Receptors for LH and FSH in largest follicles of postpartum beef cows. Biol. Reprod. 38:587-591.

Johnson, S.K., P.E. Lewis and E.K. Inskeep. 1991. Steroids and cAMP in follicles of postpartum beef cows treated with norgestomet. J. Anim. Sci. 69:3747-3753. 
Johnson, S.K., R.P. Del Vecchio, E.C. Townsend and E.K. Inskeep. 1992. Role of prostaglandin $\mathrm{F}_{2} \alpha$ in follicular development and subsequent luteal life span in early postpartum beef cows. Domestic Anim. Endocrinol. 9:49-56.

Keisler, D.H., E.K. Inskeep and R.A. Dailey. 1983. First luteal tissue in ewe lambs: Influence on subsequent ovarian activity and response to hysterectomy. J. Anim. Sci. 57:150-156.

Larson, G.H. 1987. Effect of follicular fluid on development of follicles and function and life span of the corpus luteum. Ph.D. Dissertation. West Virginia University, Morgantown.

Larson, G.H., P.E. Lewis, R.A. Dailey, E.K. Inskeep and E.C. Townsend. 1987. Follicle stimulating hormone pattern and luteal function in ewes receiving bovine follicular fluid during three stages of the estrous cycle. $J$. Anim. Sci. 64:1491-1497.

Larson, G.H., D.S. Mallory, R.A. Dailey and P.E. Lewis. 1991. Gonadotropin concentrations, follicular development and luteal function in pituitary stalktransected ewes treated with bovine follicular fluid. J. Anim. Sci. 69:4104 4111.

Lewis, G.S., A.W. Lishman, R.L. Butcher, R.A. Dailey and E.K. Inskeep. 1981. Factors affecting function of induced corpora lutea in postpartum anestrous ewes. J. Anim. Sci. 52:1122-1129.

Lishman, A.W., S.M.J. Allison, R.L. Fogwell, R.L. Butcher and E.K. Inskeep. 1979. Follicular development and function of induced corpora lutea in underfed postpartum anestrous beef cows. J. Anim. Sci. 48:867-875.

McCormick, V.I. 1988. Utero-ovarian relationships in the postpartum ewe. M.S. Thesis. West Virginia University, Morgantown.

Meisterling, E.M. and R.A. Dailey. 1987. Use of concentrations of progesterone and estradiol-17 $\beta$ in milk in monitoring postpartum ovarian function in dairy cows. J. Dairy Sci. 70:2154-2161.

Ottobre, J.S., G.S. Lewis, W.V. Thayne and E.K. Inskeep. 1980. Mechanism by which progesterone shortens the estrous cycle of the ewe. Biol. Reprod. 23:1046-1053.

Ottobre, J.S., D.L. Vincent, W.J. Silvia and E.K. Inskeep. 1984. Aspects of regulation of uterine secretion of prostaglandins during the oestrous cycle and early pregnancy. Anim. Reprod. Sci. 7:75-100.

Pratt, B.R., J.G. Berardinelli, L.P. Stevens and E.K. Inskeep. 1982. Induced corpora lutea in the postpartum beef cow. I. Comparison of gonadotropin 
releasing hormone and human chorionic gonadotropin and effects of progestogen and estrogen. J. Anim. Sci. 54:822-829.

Reber, J.E., E.K. Inskeep, R.L. Butcher, K.F. Breuel and J.C. Spitzer. 1991. Maintenance of pregnancy in postpartum cows having short-lived corpora lutea. J. Anim. Sci. 69 (Suppl. 1):2.

Sheffel, C.E. 1980. Effects of progestogens and gonadotropins on estrus and ovulation in sheep and cattle. M.S. Thesis, West Virginia University, Morgantown.

Sheffel, C.E., B.R. Pratt, W.L. Ferrell and E.K. Inskeep. 1982. Induced corpora lutea in the postpartum beef cow. II. Effects of treatment with progestogen and gonadotropins. J. Anim. Sci. 54:830-836.

Usmani, R.H., M. Ahmad, E.K. Inskeep, R.A. Dailey, P.E. Lewis and G.S. Lewis. 1985a. Uterine involution and postpartum activity in Nili-Ravi buffaloes. Theriogenology 24:435-448.

Usmani, R.H., R.A. Dailey and E.K. Inskeep. 1985b. Pattern of arterial supply to the ovaries in Nili-Ravi buffaloes: Relationship with the distribution of ovarian structures. Anim. Reprod. Sci. 8:225-234.

Usmani, R.H., R.A. Dailey and E.K. Inskeep. 1990. Effects of limited suckling and varying prepartum nutrition on postpartum reproductive traits of milked buffaloes. J. Dairy Sci. 73:1564-1570.

Villeneuve, P., R.A. Dailey, E.K. Inskeep, L.A. Guilbault and J.J. Dufour. 1989. Effect of multiple injections of $\mathrm{PGF}_{2} \alpha$ on follicular development in early postpartum ewes. J. Anim. Sci. 67 (Suppl. 1):406.

Vincent, D.L. and E.K. Inskeep. 1986. Role of progesterone in regulating uteroovarian venous concentrations of $\mathrm{PGF}_{2} \alpha$ and $\mathrm{PGE}_{2}$ during the estrous cycle and early pregnancy in ewes. Prostaglandins 31:715-733.

Vincent, D.L., S. Meredith and E.K. Inskeep. 1986. Advancement of uterine secretion of prostaglandin $E_{2}$ by treatment with progesterone and transfer of asynchronous embryos. Endocrinology 119:527-529.

White, L.M., D.H. Keisler, R.A. Dailey and E.K. Inskeep. 1987. Characterization of ovine follicles destined to form subfunctional corpora lutea. $J$. Anim. Sci. 65:1595-1601. 


\section{[Blank Page in Original Bulletin]}



m

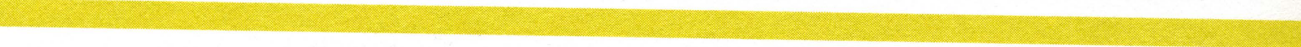

(20)

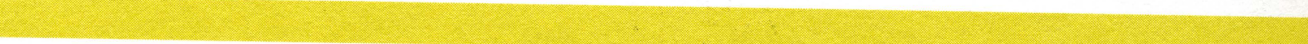
(20)

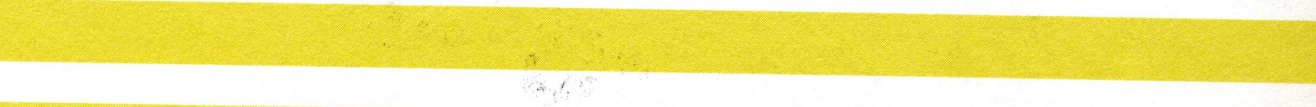

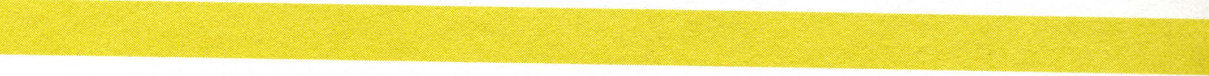

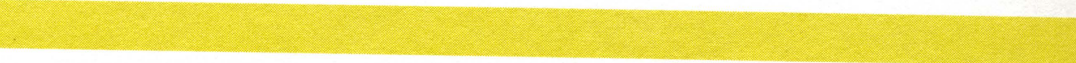
(20)

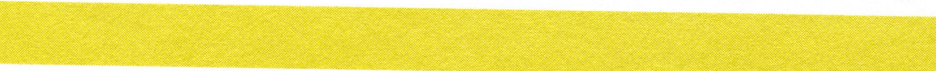
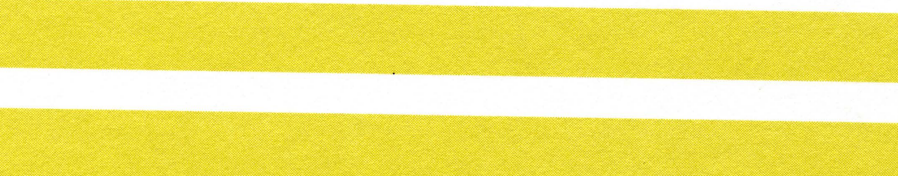